\title{
Application of the RAPD technique in tilapia fish: species and subspecies identification
}

\author{
F. BARDAKCI* \& D. O. F. SKIBINSKI \\ Molecular Biology Research Group, School of Biological Sciences, University of Wales, Singleton Park, \\ Swansea SA2 8PP, U.K.
}

\begin{abstract}
Random Amplified Polymorphic DNA (RAPD) analysis was applied to three species of the tilapia genus Oreochromis and four subspecies of $O$. niloticus. Thirteen random 10-mer primers were used to assay polymorphisms within and between populations. Different RAPD fragment patterns were observed for different species, although not always for different subspecies. Evidence is presented that RAPD markers might be useful for systematic investigation at the level of species and subspecies.
\end{abstract}

Keywords: DNA, Oreochromis, polymorphism, RAPD, systematics, tilapia.

\section{Introduction}

Tilapia are cultured extensively throughout the world, especially in Africa and the Far East. Most of the important tilapiine species used in aquaculture are members of the Oreochromis genus, as many members of this taxon grow well under diverse culture conditions (Fryer \& Iles, 1972; Pullin \& Capili, 1989). Despite its commercial importance, resources have only recently been devoted to the development of improved strains of tilapia. Moreover few efforts have been made to assess the relative value of different methods for genetic characterization of tilapia germplasm.

The most recent classification of tilapiine species is based on reproduction, development, feeding, structural characteristics and biogeography (Trewavas, 1983). However, such characters are of limited value for identification purposes because they show considerable interpopulation variation and differences between species are small (Fryer \& Iles, 1972; Abban, 1988). Protein electrophoresis has been extensively used to discriminate species of tilapia (Kornfield at al., 1979; McAndrew \& Majumdar, 1983, 1984; Abban, 1988; Sodsuk \& McAndrew, 1991) and their hybrids (Macaranas et al., 1986) but this technique could not discriminate subspecies of O. niloticus (Seyoum, 1989, cited in Seyoum \& Kornfield, 1992; Seyoum, 1990). Mitochondrial DNA markers have been used success-

*Correspondence. fully to identify the subspecies of $O$. niloticus (Capili, 1990; Seyoum \& Kornfield, 1992) but little effort has yet been devoted to the analysis of nuclear DNA for this purpose.

The development of random amplified polymorphic DNA (RAPD) markers, generated by the polymerase chain reaction (PCR), allows the examination of genomic variation without prior knowledge of DNA sequences (Williams et al., 1990, 1993; Welsh \& McClelland, 1990; Hadrys, 1992). The number and the size of amplified fragments depend on length and sequence of short, single and arbitrary primers. Priming sites are randomly distributed throughout a genome and polymorphisms in such sites result in differing amplification products, detected by the presence and absence of fragments. Such polymorphisms are inherited in a Mendelian fashion and can be used as genetic markers. The method has been successfully used to detect variation between strains of bacteria and rice (Welsh \& McClelland, 1990), mice (Welsh et al., 1991), Gliricidia (Chalmers et al., 1992), closely related species of black Aspergilli (Megnegneau et al., 1993), and cocoa (Russell et al., 1993) and between species of parasitic protozoa (Tibayrenc et al., 1993).

This paper provides evidence that RAPD markers can be used to discriminate between three widely cultivated species of tilapia and between several subspecies of Oreochromis niloticus, probably the species with greatest commercial importance. An assessment is also made of the utility of RAPD analysis for systematic analysis of tilapia. 


\section{Materials and methods}

\section{Species and subspecies studied}

The species and subspecies used in this study are held in aquaria at the University College of Swansea, Wales. Their sources are given in Table 1. O. niloticus (baobab) is a commercial strain of $O$. niloticus with possible hybrid ancestry. It is not recognized as a subspecies but is designated as one for convenience in this study.

Their sources are given in Table 1. O. niloticus (baobab) is a commercial strain of $O$. niloticus with possible hybrid ancestry. It is not recognized as a subspecies but is designated as one for convenience in this study.

\section{DNA extraction}

DNA was prepared from fin tissue following the method described by Hillis \& Moritz (1990) with some modifications. Approximately $50 \mathrm{mg}$ of the caudal fin tissue was cut into small pieces and suspended in 500 $\mu \mathrm{L}$ STE $(0.1 \mathrm{M} \mathrm{NaCl}, 0.05 \mathrm{M}$ Tris and $0.01 \mathrm{M}$ EDTA, $\mathrm{pH} 8$ ). After adding $30 \mu \mathrm{L}$ SDS (10 per cent) and 30 $\mu \mathrm{L}$ proteinase $\mathrm{K}\left(10 \mathrm{mg} \mathrm{mL} \mathrm{m}^{-1}\right)$, the mixture was incubated at $50^{\circ} \mathrm{C}$ for $30 \mathrm{~min}$. DNA was purified by successive extraction with phenol, phenol:chloroform:isoamyl alcohol (25:24:1) and chloroform:isoamyl alcohol (24:1), respectively. DNA was precipitated with ice-cold absolute ethanol and washed with 70 per cent ethanol. The pellet was dried and resuspended in 150 $\mu \mathrm{L}$ TE (10 mM Tris- $\mathrm{HCl}, 1 \mathrm{~mm} \mathrm{Na} \mathrm{NaDTA}_{2} \mathrm{H}_{2} \mathrm{O}, \mathrm{pH}$ 7.2).

\section{Amplification conditions and electrophoresis}

A set of 13 decamer primers from Operon Technologies was used in this study (Table 2). The amplification conditions were based on Williams et al. (1990) with some modifications. Amplification reactions were performed in $500 \mathrm{~mm} \mathrm{KCl}, 100 \mathrm{~mm}$ Tris $\left(\mathrm{pH} 9.0\right.$ at $25^{\circ} \mathrm{C}$ ), 1 per cent Triton X-100, $2.5 \mathrm{~mm} \mathrm{MgCl}, 100 \mu \mathrm{M}$ each of dATP, dTTP, dGTP and dCTP (Pharmacia), 5 pmoles of 10-base primer, 0.5 units of Taq DNA polymerase (Promega Biotec.), and $20 \mathrm{ng}$ of genomic DNA in a final volume of $25 \mu \mathrm{L}$. The mixture was overlaid with the same volume of mineral oil. DNA amplification was performed in a thermal cycler (Hybaid, U.K.). For the first cycle, denaturation, annealing and extension were $94^{\circ} \mathrm{C}$ for $2 \mathrm{~min}, 35^{\circ} \mathrm{C}$ for $1 \mathrm{~min}$ and $72^{\circ} \mathrm{C}$ for 2 min, respectively. Denaturation time was decreased to $30 \mathrm{~s}$ for the following 44 cycles. One negative control (absence of template DNA) was performed for each set of amplifications.

Approximately $10 \mu \mathrm{L}$ of amplification products were separated on 5 per cent vertical nondenaturing polyacrylamide gels in TBE buffer $(0.89 \mathrm{M}$ Tris, $0.89 \mathrm{M}$ boric acid and $0.11 \mathrm{~m}$ EDTA, $\mathrm{pH} 8.3$ ). Gels were fixed with 10 per cent ethanol and 0.5 per cent acetic acid solution twice for $3 \mathrm{~min}$, stained with 0.1 per cent silver

Table 2 Sequence and operon codes of the random primers used to study variation in Oreochromis species

\begin{tabular}{ll}
\hline Primer codes & Sequence $\left(5^{\prime}\right.$ to $\left.3^{\prime}\right)$ \\
\hline OPA 03 & AGTCAGCCAC \\
OPA 04 & AATCGGGCTG \\
OPA 05 & AGGGGTCTTG \\
OPA 07 & GAAACGGGTG \\
OPA 08 & GTGACGTAGG \\
OPA 10 & GTGATCGCAG \\
OPA 12 & TCGGCGATAG \\
OPA 13 & CAGCACCCAC \\
OPA 17 & GACCGCTTGT \\
OPA 19 & CAAACGTCGG \\
OPB 08 & GTCCACACGG \\
OPC 02 & GTGAGGCGTC \\
OPC 11 & AAAGCTGCGG \\
\hline
\end{tabular}

Table 1 Species and subspecies used in this study and their source

\begin{tabular}{lll}
\hline Species and subspecies & Abbreviation & Source \\
\hline $\begin{array}{lll}\text { Oreochromis aureus } \\
\text { Oreochromis mossambicus }\end{array}$ & Aur & Lake Manzala, Egypt \\
$\begin{array}{l}\text { Oreochromis niloticus } \\
\text { O. } n \text {. vulcani (vulcani) }\end{array}$ & Vul & Aquarist stock \\
$\begin{array}{l}\text { On. baringoensis (baringo) } \\
\text { O. n. niloticus (manzala) }\end{array}$ & Bar & Lake Vulcani, Kenya \\
$O . n$. (baobab) & Bil & Lake Baringo, Kenya \\
& Bao & Lake Manzala, Egypt \\
\end{tabular}

Common names of $O$. niloticus subspecies are given in brackets.

Nomenclature according to Trewavas (1983). 

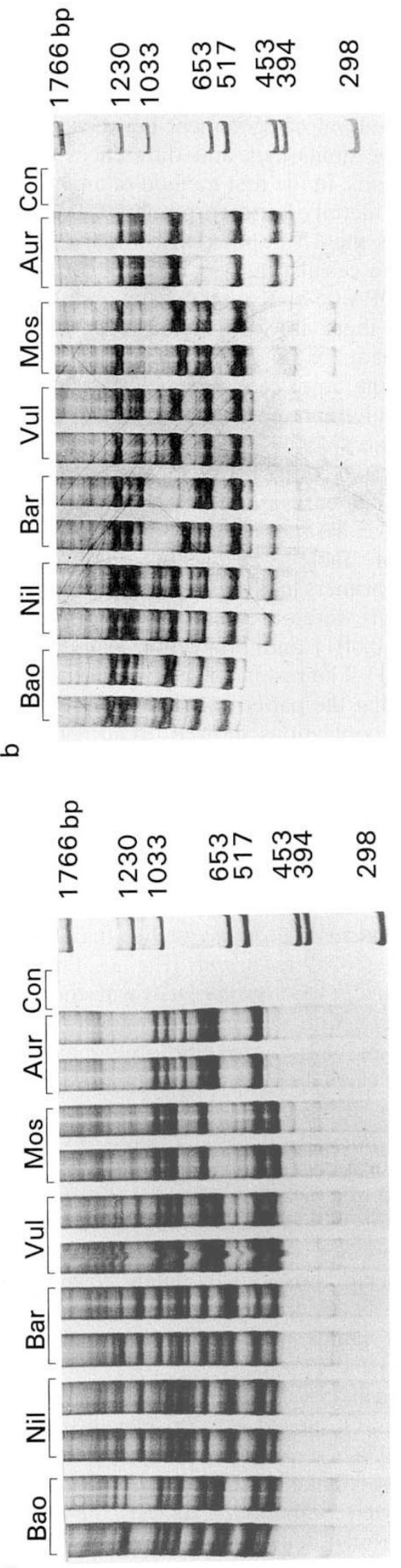

nitrate solution for $10 \mathrm{~min}$, rinsed twice with distilled water, and then developed in an alkaline solution (1.5 per cent $\mathrm{NaOH}, 0.1$ per cent $\mathrm{NaBH}_{4}$ and 0.15 per cent $\mathrm{CH}_{2} \mathrm{O}$ ). A total of four individuals per species and subspecies (two males and two females) were analysed. Silver staining of polyacrylamide gels was found to be far superior to ethidium bromide staining of agarose gels in terms of the number of fragments that could be resolved clearly.

\section{Analysis}

The RAPD patterns of individuals were compared within and between populations. Fragments were scored as 1 if present or 0 if absent. The index of similarity between individuals was calculated using the formula:

$S_{x y}=2 n_{x y} /\left(n_{x}+n_{y}\right)$,

where $n_{x y}$ is the number of fragments shared by individuals $x$ and $y$ and $n_{x}$ and $n_{y}$ are the number of fragments scored for each individual (Lynch, 1990). Within population similarity $(S)$ is calculated as the average of $S_{x y}$ across all possible comparisons between individuals within a population.

Between population similarity, corrected for within population similarity, is:

$S_{i j}=1+S_{i j}^{\prime}-0.5\left(S_{i}+S_{j}\right)$,

where $S_{i}$ and $S_{j}$ are the values of $S$ for populations $i$ and $j$, respectively and $S_{i j}^{\prime}$ is the average similarity between randomly paired individuals from populations $i$ and $j$ (Lynch, 1990). It is possible for the value of $S_{i j}$ to exceed 1.

$S_{i j}^{\prime}$ was also converted to a measure of genetic distance $\left(D_{i j}\right)$ using the equation:

$D_{i j}^{\prime}=-\ln \left[S_{i j}^{\prime} / \sqrt{ }\left(S_{i} S_{j}\right)\right]$, (Lynch, 1991).

$D_{i j}^{\prime}$ values were used to construct dendrograms using the unweighted pair-group method of analysis (UPGMA) (Sneath \& Sokal, 1973).

The statistics can be calculated for each primer separately or for the combined data for all primers.

\section{Results}

All the primers examined produced different RAPD fragment patterns (Fig. 1). The number of fragments generated per primer varied between six and 17. All primers gave species-specific RAPD patterns. Sub-

Fig. 1 RAPD patterns from each of six populations using (a) primer OPA 04 and (b) OPA 07. Samples (reading from the right hand lane): size markers; negative control (no template), $O$. aureus, O.mossambicus, O.n. vulcani, O.n. baringoensis, O. n. niloticus, O. $n$. (baobab). 


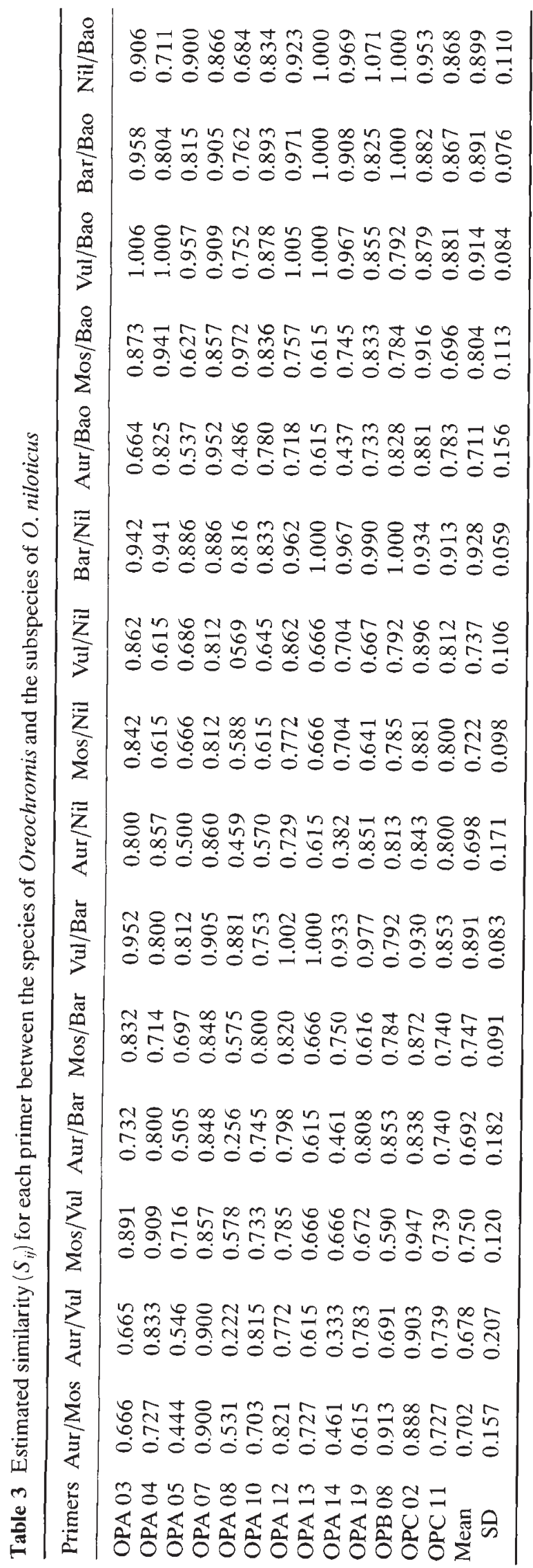

species-specific patterns were obtained for some but not all primers. Values of similarity $\left(S_{\mathrm{ij}}\right)$ between populations for each primer are given in Table 3. ITwo analyses were carried out on the data in Table 3 to assess the level of agreement between primers in the pattern of similarities and differences in population comparisons. In the first method of analysis, the correlation in identity between primers OPA 03 and OPA 04 across the 15 population comparisons was calculated. The calculation was repeated for primers OPA 03 and OPA 05 and so on for all possible primer pairs of which there are 78 in total. Nineteen values were significant at the 1 per cent level and a further 12 significant at the 5 per cent level. All the significant values were positive and the average correlation was 0.482 . In a factor analysis on the matrix of identity values, the first principal component explained 45 per cent of the variance in identity. In the second method of analysis a two-way analysis of variance was carried out on the values of Table 3 using the two-way interaction between primers and population pairs as error. Significant effects were observed both for primers $\left(F_{12.168}=\right.$ $9.9, P<0.001)$ and population pairs $\left(F_{14,168}=11.4\right.$, $P<0.001)$. The results of the two methods of analysis suggest that the pattern of similarities and differences between populations showed broad agreement across primers but that the overall level of similarity varied between primers.

The highest value of within-population similarity $(S)$ was obtained for $O$. mossambicus, the lowest for $O$. $n$. (baobab) (Fig. 2). The similarities between the subspecies of $O$. niloticus (except between $O . n$. vulcani and $O$. $n$. niloticus) are clearly higher than those between the species of Oreochromis (Fig. 3). The dendrogram (Fig. 4) links O.n. mossambicus with the subspecies of $O$. niloticus, with $O$. aureus as outgroup. To assess the significance of this grouping a compatibility analysis has been carried out by constructing separate dendrograms for each of the 13 primers. Because there were four $O$. niloticus subspecies, there were $4 \times 13=52$ possible dendrograms involving $O$. aureus, $O$. mossambicus and one of the $O$. niloticus subspecies. Of these, the majority (a total of 25) had O. aureus, rather than another species, as outgroup. If the expectation that the three species are equally likely to be outgroup is assumed as the null hypothesis, the expected number of dendrograms with $O$. aureus as outgroup is $52 /$ $3=17.33$ and $\chi_{1}^{2}=5.088(P<0.05)$ and the null hypothesis can be rejected. The favoured outgroup is thus $O$. aureus. Of the three subspecies (disregarding $O . n$. (baobab)), O. n. baringoensis and $O$. n. niloticus are more closely linked with $O$. n. vulcani as outgroup (Fig. 4). Applying compatibility analysis, the number of individual primer dendrograms with $O . n$. baringoensis, 
Fig. 2 Average similarity $(S)$ across primers within species of Oreochromis and subspecies of $O$. niloticus with 95 per cent confidence intervals.
Fig. 3 Similarity $\left(S_{i j}\right)$ across primers between species of Oreochromis and subspecies of $O$. niloticus with 95 per cent confidence intervals.

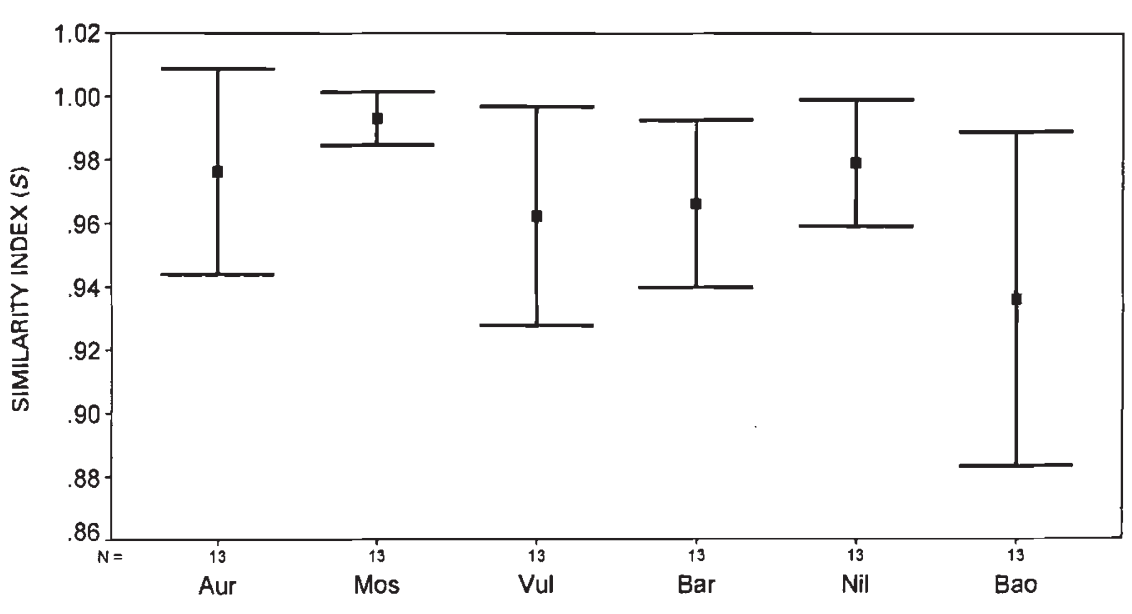

$N=$ Number of primers SPECIES AND SUBSPECIES

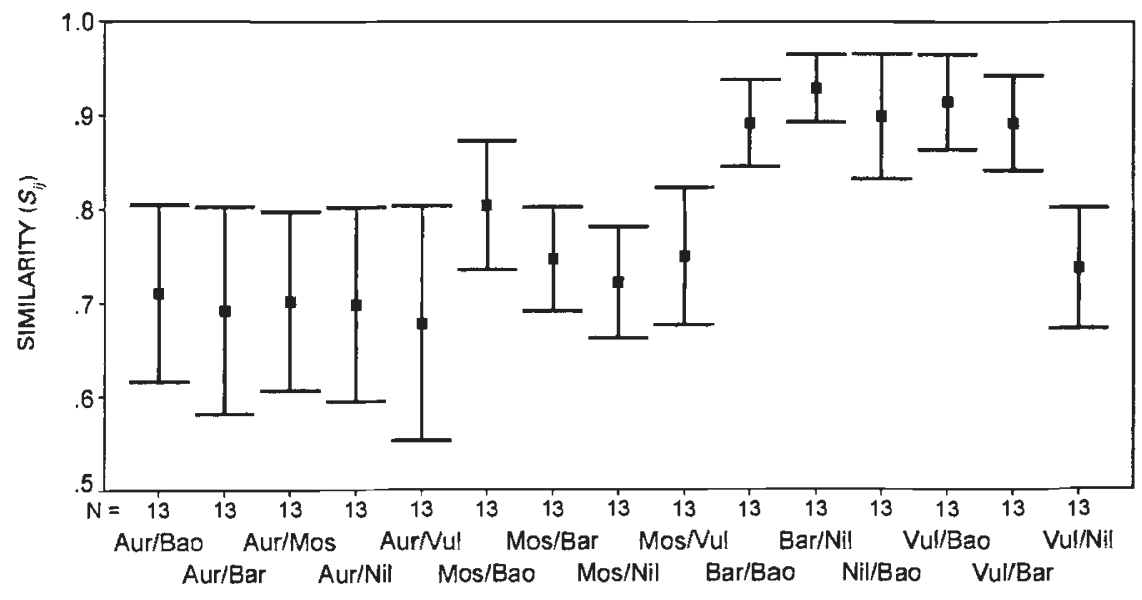

$\mathrm{N}=$ number of primers
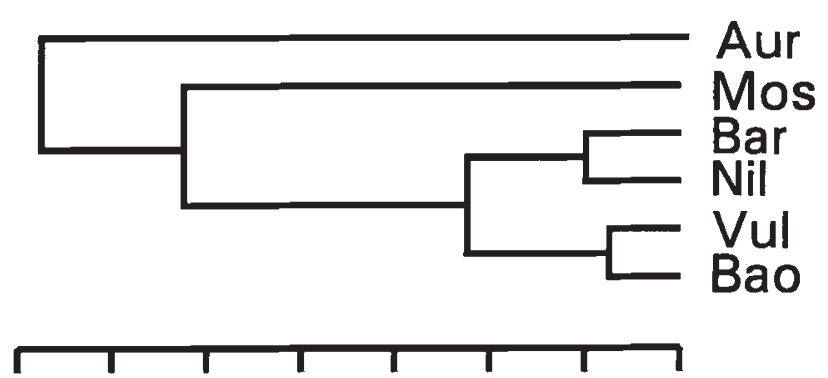

$\begin{array}{llllllll}0.35 & 0.30 & 0.25 & 0.20 & 0.15 & 0.10 & 0.05 & 0.00\end{array}$

\section{GENETIC DISTANCE $\left(D_{i j}^{\prime}\right)$}

Fig. 4 UPGMA dendrogram of the species of Oreochromis and the subspecies of $O$. niloticus based on values of genetic distance $\left(D_{i j}^{\prime}\right)$ calculated from data for all primers.
$O . n$. vulcani and $O . n$. niloticus as outgroup are zero, eight and five, respectively. Under the null hypothesis that the three dendrograms should be equally frequent, $\chi_{2}^{2}=7.544(P<0.05)$. Thus the hypothesis that $O . n$. baringoensis is the outgroup can be rejected. $O . n$. vulcani is favoured as the outgroup since it occurs in the largest number of individual primer dendrograms.

\section{Discussion}

In common with other molecular techniques, RAPD analysis has been successful in identifying markers which distinguish tilapia species, although individual primers differ significantly in the amount of interpopulation variation they detect. RAPD analysis has 
also identified DNA markers which can distinguish subspecies of Oreochromis niloticus and in this respect has been more successful than allozyme analysis (Seyoum, 1989, cited in Seyoum \& Kornfield, 1992; Seyoum, 1990). Mitochondrial DNA analysis has also revealed differences between subspecies of $O$. niloticus (Seyoum \& Kornfield, 1992) but might have some disadvantages in studies of population differentiation compared with nuclear markers. This is because of evidence that mtDNA gene flow can occur across hybrid zones, in the absence of nuclear gene flow, in some animals (Ferris et al., 1983; Tegelstrom, 1987). The tilapia species studied here hybridize readily in captivity, therefore the opportunity for mtDNA introgression is great.

Intrapopulation RAPD variation was detected with all primers. This suggests that RAPD analysis might be more sensitive than mtDNA analysis which has failed to reveal variation within tilapia populations (Capili, 1990; Seyoum \& Kornfield, 1992). In the present study, levels of intrapopulation variation are expected to be low because most of the subspecies used were founded, and have been propagated, from relatively small numbers of individuals. The population of $O$. mossambicus is descended from a single sib-mating and has the lowest level of variation.

In the widely accepted classification of tilapia of Trewavas (1983), O. aureus and O. niloticus are placed in a different subgenus from $O$. mossambicus. The allozyme studies of McAndrew \& Majumdar (1984) and Sodsuk \& McAndrew (1991), favoured either this classification or the closer linking of $O$. mossambicus with $O$. aureus. The RAPD results are at variance with these studies in suggesting a closer relationship between $O$. mossambicus and $O$. niloticus. In the mtDNA study of Seyoum \& Kornfield (1992), O. $n$. niloticus was more similar to $O$. $n$. vulcani than to $O$. $n$. baringoensis. The compatibility analysis gives least support of all to this hypothesis. The evidence of highly significant differences between population pair similarity values provides support for the reliability of the technique as a tool for detecting genetic differences between populations.

RAPD analysis has been used for constructing trees in other organisms (Chalmers et al., 1992; Kaemmer et al., 1992; Megnegneau et al., 1993; Tibayrenc et al., 1993). We have observed that small alterations in PCR parameters or quality of target DNA can radically alter RAPD patterns (see also, Devos \& Gale, 1992; Williams et al., 1993). Thus there may be reason to view with caution systematic conclusions based on RAPD analysis alone. On the other hand, the possibility of carrying out compatibility analysis with unlimited numbers of primers, each detecting variation at several regions in the genome, provides an advantage over other techniques. Even if some primers amplify identical regions of the genome or if the technique itself is noisy, it should be possible to build up quickly a consensus from patterns of interpopulation variation.

\section{Acknowledgements}

We thank K.A. Naish for advice on computer analysis. F. Bardakci is supported by the University of Cumhuriyet, Turkey. This work was funded in part by grants from the Overseas Development Administration of the U.K. to J.A. Beardmore, G.C. Mair and D.O.F. Skibinski.

\section{References}

ABBAN, E. K. 1988. Taxonomy and Biochemical Genetics of some African Freshwater Fish Species. Ph.D. Thesis, University of Wales.

CAPILI, J. B. 1990. Isozyme and Mitochondrial DNA Restriction Endonuclease Analysis of Three Strains of O. niloticus. Dissertation, University of Wales.

CHALMERS, K. J., WAUGH, R., SPRENT. J. I., SIMONS, A. J. AND POWELL, w. 1992. Detection of genetic variation between and within populations of Gliricidia sepium and $G$. maculata using RAPD markers. Heredity, 69, 465-472.

DEVOS, K. M. AND GALE, M. D. 1992. The use of random amplified polymorphic DNA markers in wheat. Theor. Appl. Genet., 84, 567-572.

FERrIS, S. D., SAGE, R. D., HUANG, C. M., NIELSEN, J. T., RITTE, U., WILSON, A. C. 1983. Flow of mitochondrial DNA across a species boundary. Proc. Natl. Acad. Sci. U.S.A., 80, 2290-2294.

FRYER, G. AND ILES, T. D. 1972. The Cichlid Fishes of the Great Lakes of Africa. Oliver and Boyd, Edinburgh.

HADRYS, H., BALICK, M. AND SCHIERWATER, B. 1992. Application of random amplified polymorphic DNA (RAPD) in molecular ecology. Mol. Ecol., 1, 55-63.

HILlIS, D. M. AND MORITZ, C. 1990. Molecular Systematics. Sinauer Associates, Sunderland, MA.

KAEMMER, D., AFZA, R., WEISING, K., KAHL, G. AND NOVAK, F. J. 1992. Oligonucleotide and amplification fingerprinting of wildspecies and cultivars of banana (Musa spp.). Bio/ Technology, 10, 30-35.

KORNFIELD, 1. L., RITTE, U., RICHLER, C. AND WAHRMAN, J. 1979. Biochemical and cytological differentiation among cichlid fishes of the Sea of Galilee. Evolution, 33, 1-14.

LYNCH, M. 1990. The similarity index and DNA fingerprinting. Mol. Biol. Evol., 7, 478-484.

LYNCH, M. 1991. Analysis of population genetic structure by DNA fingerprinting. In: Burke, T., Dolf, G., Jeffreys, A.J. and Wolf, R. (eds) DNA Fingerprinting Approaches and Applications, pp. 113-126. Basel, Switzerland.

McANDREW, B. J. AND MAJUMDAR, K. C. 1983. Tilapia stock identification using electrophoretic markers. Aquaculture, 30, 249-261. 
McANDREW, B. J. AND MAJUMDAR, K. C. 1984. Evolutionary relationships within three Tilapiine genera (Pisces: Cichlidae). Zool. J. Linn. Soc., 80, 421-435.

MACARANAS, J. M., TANIGUCHI, N., PANTE, M. J. R., CAPILI, J. B. AND PULLIN, R. S. V. 1986. Electrophoretic evidence for extensive hybrid gene introgression into commercial $O$. niloticus $(\mathrm{L}$. stocks in the Philippines. Aqua. Fish. Manag., 17, 249-268.

MEGNEGNEAU, B., DEBETS, F. AND HOEXTRA, R. F. 1993. Genetic variability and relatedness in the complex group of black Aspergilli based on random amplification of polymorphic DNA. Curr. Genet., 23, 323-329.

PULlin, R. S. v. AND CAPILI, J. B. 1989. Genetic improvement of tilapias: problems and prospects. In: Pullin, R. S. V., Bhukaswan, T., Tanguthai, K. and Maclean, J. L. (eds) The Second International Symposium on Tilapia in Aquaculture; ICLARM Conference Proceedings 15, pp. 259-266. Manila.

RUSSELL, J. R., HOSEIN, F., JOHNSON, E, WAUGH, R. AND POWELL, W. 1993. Genetic differentiation of cocoa (Theobroma cacao L.) populations revealed by RAPD analysis. Mol. Ecol., 2, 89-97.

SEYOUM, s. 1990. Allozyme variation in subspecies of Oreochromis niloticus. Isozyme Bull., 23, 97.

SEYOUM, S. AND KORNFIELD, I. 1992. Identification of the subspecies of Oreochromis niloticus (Pisces:Cichlidae) using restriction endonuclease analysis of mitochondrial DNA. Aquaculture, 102, 29-42.

SNEATH, P. H. A. AND SOKAL, R. R. 1973. Numerical Taxonomy. W.H. Freeman, San Francisco.
SODSUK, P. AND McANDREW, B. J. 1991. Molecular systematics of three tilapiine genera Tilapia, Sarotherodon and Oreochromis using allozyme data. J. Fish Biol., 39, 301-308.

TEGELSTROM, H. 1987. Transfer of mitochondrial DNA from the northern red-backed vole (Clethrionomys rutilus) to the bank vole (C. glareolus). J. Mol. Evol., 24, 218-227.

TIBAYRENC, M., NEUBAUER, K., BARNABE, C., GUERRINI, F., SKARECKY, D. AND AYALA, F. J. 1993. Genetic characterization of six parasitic protozoa: Parity between random-primer DNA typing and multilocus enzyme electrophoresis. Proc. Natl. Acad. Sci. U.S.A., 90, 1335- 1339.

TREWAVAS, E. 1983. Tilapiine fishes of the genera Oreochromis, Sarotherodon and Danakilia. British Museum of Natural History, London.

WELSH, J. AND McCLELLAND, M. 1990. Fingerprinting genomes using PCR with arbitrary primers. Nucleic Acids Res., 18, 7213-7218.

WElsh, J., PETERSON, C. AND McClelland, M. 1991. Polymorphisms generated by arbitrarily primed PCR in the mouse: application to strain identification and genetic mapping. Nucleic Acids Res., 19, 303-306.

WILLIAMS, J. G. K., HANAFEY, M. K., RAFALSKI, J. A. AND TINGEY, S. V. 1993. Genetic analysis using random amplified polymorphic DNA markers. Methods Enzymol., 218, 704-740.

WILLIAMS, J. G. K., KUBELIK, A. R., LIVAK, K. J., RAFALSKI, J. A. AND TINGEY, S. V. 1990. DNA polymorphisms amplified by arbitrary primers are useful as genetic markers. Nucleic Acids Res., 18, 6531-6535. 